\section{Equine Virtue}

\author{
Paul Schollmeier \\ University of Nevada, Los Vegas
}

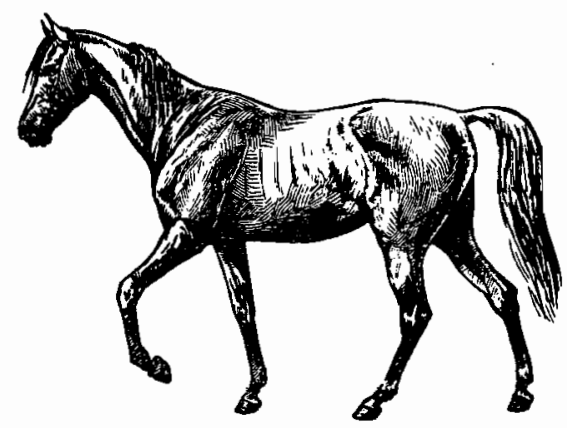

I

Aristotle presents the reader of his Nicomachean Ethics with many passages worthy of curiosity. One passage of this curious sort also happens to be of interest to those who love animals. This passage asserts, among other things, that a horse has virtue. What I wish to do is to ask whether we can take Aristotle's assertion seriously. We shall see that we can indeed. This passage will provide us not only with a new perspective on the classical conception of virtue but also with a new insight into the admirable virtue of our equine companions. This new insight in its turn suggests that animal ethics might find a new basis in what we today term virtue ethics.

\section{II}

We probably ought to begin with a look at the passage in question. The passage is part of an argument proving that moral virtue is a habit which lies on a mean. Artistotle begins the argument with the general proposition that all virtue brings that which possess it into good condition and makes its function good ( $N E$.

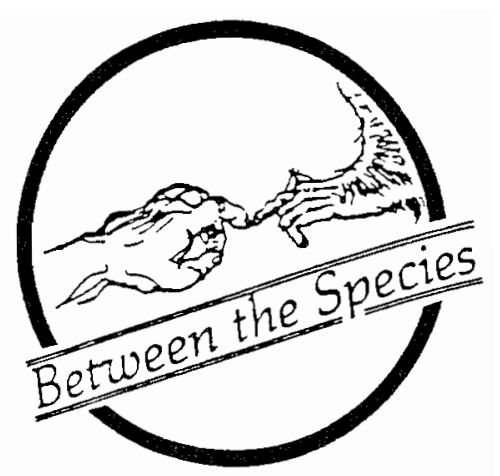

2.6., 1106a15-17). From this proposition he draws the corollary that human virtue is a habit which makes us good and makes us perform our function well (1106a21-24).

To prove the general proposition, Aristotle makes the assertion which has piqued our curiosity:

Similarly the virtue of a horse makes the horse both good and good at running and at carrying its rider and at awaiting the enemy (NE. 2.6., 1106a19-21). ${ }^{1}$

Actually this sentence asserts merely that the virtue of a horse makes a horse good, and that its virtue makes its function good. But the sentence clearly implies that a horse has virtue. ${ }^{2}$

Now the implication that a horse has virtue seems absurd on Aristotle's own account of virtue. On his account only human beings appear to have the rationality necessary for the acquisition of virtue. Aristotle argues that human rationality has two parts. The one part is theoretical, and the other part practical (NE. 6. 1., 1139a6-11). Though the theoretical part cannot, the practical part can create virtue. The theoretical part only grasps truth, but the practical part both grasps truth and controls desire. Aristotle explicitly argues only that the practical part grasps truth and agrees with desire:

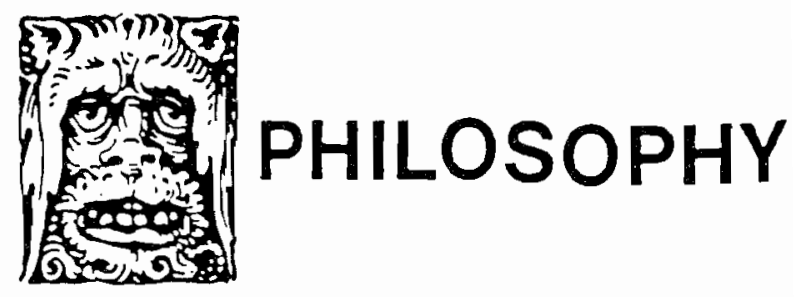


Of the intellect which is theoretical, neither practical nor productive, the functions which are good and bad are truth and falsity, for these are the functions of all intellectual faculties. Of the intellect which is practical, the good function is truth in agreement with right desire (NE. 6. 2., 1139a27-31).

But he also implies that the practical intellect agrees with right desire because it makes desire right:

The appetitive part in a strong-willed man obeys a principle. And in the temperate and courageous man it is even more obedient. For on all matters it speaks with the same voice as a principle. (NE. 1. 13., 1102b26-28).

The practical part would appear to command desire, for desire obeys its principle in those who are virtuous or strong-willed.

Indeed our practical intellect so informs desire with its principle that it makes desire more rational:

And if it is necessary to say that the irrational part has a principle, the part having a principle will be twofold. The one part has a principle in the chief sense and in itself, and the other part has a principle as listening to it as if to its parent (NE. 1. 13., 1103a1-3).

The rational part having a principle in the chief sense would be our rationality, and the rational part having a principle in the sense of listening to one would be our desire.

Aristotle also reminds us that our practical rationality itself divides into two parts. The one part concerns the ends of our action, and the other concerns the means to our ends. The part concerned with our ends is practical intuition. Aristotle is not completely explicit about what function practical intuition has. But he does appear to assert that intuition of this kind concerns practical facts which are principles of action:

The first principles of that for the sake of which are the ultimate facts themselves, for from the particulars arise the universals. Of these, we must therefore have apperception, and this apperception is intuition (NE.6.11., 1143b4-5).
He asserts in effect that practical intuition grasps the ultimate facts and that the ultimate facts include the principles for the sake of which we act. These principles are universals which arise from particulars. ${ }^{3}$

He is quite explicit about the part concerned with means. He clearly asserts that deliberation concerns the means to our ends (NE. 3. 3., 1112b32-34). And he uses examples from the professions to show that we assume our ends and deliberate about our means (NE. 3. 3., 1112b11-16).

And Aristotle argues that when we use our rationality to act, we are also able to develop habits which correspond to our actions:

In a word habits thus arise out of similar activities. That is why it is necessary to exhibit activities of a certain kind. For habits correspond to differences among these activities (NE. 2. 1., 1103b21-23).

Of course the actions to be performed ought not to be excessive or deficient. They can only be in accordance with a mean (NE. 2. 2., 1104a20-27 and NE. 2. 6., 1106a24-1106b7).

We thus see that we must have a practical rationality with practical intuition and deliberation in order to develop moral virtue. But rationality of this sort is the very property which distinguishes us from other animals. Aristotle makes this fact clear when he defines the human function:

What can the human function be? Life appears to be common to plants. But we seek what is peculiar to human beings. The life of nutrition and growth must therefore be excluded. A life of perception follows. But this life appears to be common to a horse and an ox and all animals. A practical life of the part having a principle then remains (NE. 1.7., 1097b3311098a4).

Please notice that he explicitly cites the horse as an example of an animal which does not have a rational life. A horse has only a life of perception and nutrition.

A horse would consequently appear to have only what Aristotle calls virtue in the natural sense. He argues that the presence of practical rationality is what distinguishes virtue in the full sense from virtue in the natural sense: 
If a man acquires practical intuition, there is a difference in his action. His habit will be similar to natural virtue, but it will be virtue in the chief sense (NE. 6. 13., 1144b12-14).

Virtue in the natural sense is only a natural ethical quality:

All people think that each of the ethical characteristics belongs somehow by nature to those who have them. For we are just and temperate and courageous from the moment of birth (NE. 6. 13., 1144b4-6).

Virtue of this sort especially exists in children and in other animals ( $N E$. 6. 13., 1144b8-9). In a word, it is an instinct.

\section{III}

But if we take another look at the passage in question, we can see that the equine virtue under discussion cannot be virtue in the natural sense. For this virtue not only makes a horse good, it also makes a horse good at performing its function. But the functions mentioned do not appear to be functions entirely natural to a horse. Though it can perform them, a horse does not perform these functions on its own. One surely would not think that a horse naturally carries another animal on its back, let alone does so well. Nor would one be apt to think that a horse quietly awaits its enemy. One might think that a horse naturally runs well. But we shall see that it in fact does not.

Aristotle would thus appear to write of some conception of virtue other than virtue in the strict sense or in the natural sense. He appears to discuss a conception of what I shall call a hybrid virtue. What is a hybrid virtue? A virtue of this sort appears to be a cross between human virtue in the strict sense and animal virtue in the natural sense. This virtue is partially human and partially animal.

But how does a hybrid virtue arise? We have seen that our practical rationality enables us to grasp a practical principle and to control our instincts. And with this understanding and control we can develop virtue and improve our function. What we shall now see is that our practical rationality also enables us to develop virtue in other animals and to improve their function. We can use our rationality to understand an animal and to control its instincts through rewards and punishments. We can thus develop hybrid virtues in an animal by training it. And we may do so even though an animal does not itself have a rationality enabling it to develop its own virtue and improve its function. If it does have rationality, a horse at least does not appear to have a practical rationality sufficient to develop virtues for the functions under consideration. ${ }^{4}$

We need not turn far afield for a confirmation of our conjecture about horses and their virtue. Xenophon wrote a treatise on equitation. And though it is the earliest work extant, his treatise is still recognized today as authoritative on matters treated by him. ${ }^{5}$ But more importantly his work illustrates how we can instill practical principles in a horse and develop virtues in it. These principles, Xenophon himself asserts, will enable a horse to perform better those functions for which it has a capacity (On Equitation 3. 7-8.).

Because he was concerned with cavalry horses, Xenophon considers the functions of running and carrying a rider together. And he accordingly concerns himself with how to train a horse for the end of performing military maneuvers. He finds the means for performing these maneuvers in an enhanced capacity for running and turning. He consequently recommends the volte, which is a turning exercise, and the ellipse, which apparently combines running and turning:

We recommend the exercise called the volte because it accustoms a horse to turn on both jaws. To change the direction of the exercise is also good in order that both jaws may be balanced by each change of exercise. But we recommend the ellipse rather than the circle, for a horse will turn more gladly, having had its fill of the stretch. And it will thus practice straight running and turning at the same time $(E Q .7 .13-14 .)^{6}$

He also argues that a horse ought to be trained to stop and to start all of a sudden ( $E Q 7.18$.), to be able to run up, down, and across hills, and to leap up and down banks and across ditches (EQ. 8. 1.).

When he explains how to turn, he makes explicit the military principle behind these exercises:

Whenever the horse faces the stretch after finishing a turn, at that very instant urge it on 
at a fast speed. For it is clear that in war turns are for the sake of attacking or retreating. To practice running at the fastest speed after making a turn is therefore a good exercise $(E Q .7 .17$.).

To perform sudden stops and starts would also be useful for attack and retreat (see again $E Q$. 7. 18.). And presumably so would the ability to negotiate uneven terrain.

Xenophon is not all work and no play, however. He does present some recommendations for dressage functions, which for him serve in parades. He even appears to explain how to train a horse for the pasade:

Now when a horse plants its hind legs under it, if you pull it back with the bit, it will bend its hind legs at the hocks and raise its front quarters so that those who are in front can see its belly and sheath. When it does this, it is necessary to give it the bit so that it will seem to those who look on that it performs all on its own the prettiest feat of a horse $(E Q .11 .3$.).

And for both campaigns and parades Xenophon also discusses qualities desirable in the movement of a horse. He especially recommends collection. This quality refers to gathering the legs of a horse under it. He argues that it increases stability in tums:

It is necessary to collect a horse in the turns because it is neither easy nor safe for it to make short turns at full speed, especially if the ground is hard or slippery. When he collects it, the rider must with the bit allow the horse to lean as little as possible, and he must lean as little as possible himself. If not, he must surely know that trivial things will be sufficient to cause both himself and the horse to fall flat (EQ. 7. 15-16.).

He also recommends collecting a horse when leaping over ditches (EQ. 8. 5.).

By taking it through its paces, a human being can thus develop virtue in a horse and enable it to perform better the functions of running and of carrying a rider. Oddly enough, Xenophon says very little about training a horse to await the enemy. But he does recommend that a horse be trained to overcome its shyness of any object which might be fearful to it (EQ.6. 14-15), and that a colt be accustomed to crowds and to sights and sounds of all sorts (EQ.2.5.).

To supplement what Xenophon has written, we might briefly consider a modern treatise on equitation. Harry Boldt has written a treatise on dressage functions which serve for equestrian competition. ${ }^{7}$ And he too discusses qualities of the movement of a horse. The quality most significant for us is straightness. This quality especially indicates why a horse can run better after being trained. A horse naturally has a quality called crookedness, which resembles handedness in a human being. It causes a horse to favor one side:

The horse is however naturally crooked. The hind feet do not track into the hoofprints of the corresponding front feet. As a rule horses are crooked from their right hind quarter in the direction of the left front quarter. That is to say, the left hind foot will tread in between the hoofprints of the forelegs and the right hind foot will tread outside of the right foreleg. The right hind foot will therefore be placed not under the belly of the horse but alongside of the horse (Boldt, ch. 3, p. 114). ${ }^{8}$

When straightened with exercises, a horse can run better and carry a rider better. For it has improved pushing and carrying ability, and it has greater flexibility and is more relaxed (Boldt, ch. 3, pp. 114-115). ${ }^{9}$

We see then that we can use our rationality and its principles to develop virtues in a horse and to improve its functions. And we may of course use other principles besides those of cavalry and dressage. These other principles would include the principles of working, hunting, racing, jumping, driving, playing games, and simply riding. ${ }^{10}$

\section{IV}

Perhaps we ought now to consider some objections which someone might raise against our conception of a hybrid virtue. One might ask how an equine virtue in our hybrid sense could be more than a natural virtue. Aristotle himself argues that only by its presence does practical rationality distinguish virtue in the strict sense from virtue in the natural sense (see again $N E .6 .13$., 1144b12-14). But we seem to admit that practical rationality is not present in a hybrid virtue. We use our own rationality to create moral virtue in an animal 
which appears to have no rational part. And our rationality obviously cannot be present in an animal of such sort.

Our answer to this objection would be that practical rationality is obviously present in the rational part of whoever rides a horse. We use our rationality not only to train a horse but also to guide a horse after it has been trained. Xenophon himself implies that we must use our rationality to ride a horse when he tells us of the one great precept of equitation. This precept is never to approach a horse in a fit of anger (EQ.6.13.) And Boldt emphasizes that we must have concentration when we ride. Only good concentration enables a horse to maintain its composure (Boldt, ch. 3, p. 118).

We can also see that our rationality is present in the irrational part of the horse too. For we have instilled the practical principles of equitation in the habits of the horse. Indeed Boldt argues that a rider can best develop concentration and inner calm on a trained horse (Boldt, ch. 3, p. 118).

We would however note that practical rationality of a sort lesser than human rationality does appear to be present in horses, and that a horse can sometimes use this limited rationality to exercise a hybrid virtue and perform its function. Stock horses offer a conspicuous example of this fact. A cutting horse apparently learns almost by itscl how to cut a cow from a herd. The rider has to guide the horse initially to give it an idea of what it is to do. But after a few sessions the rider nced only ride, and the horse will "work on its own." The horse will also gradually improve its ability to perform this task (Williamson, pp. 94-96). ${ }^{11}$

One might also object that moral virtue by definition requires a mean (see (NE. 2. 2., 1104a20-27 and NE. 2. 6., 1106a24-1106b7), and we have discussed no mean with regard to training horses. Though we did not discuss it, equine virtuc does however lic on a mean. Xenophon argues that a horse ought not to be forced to run too far for its strength. He does so on the grounds that nothing excessive is pleasant for horses or for humans $(E Q .10 .14$.). Boldt also argues that one ought not to overexcrcise a horse. And that every week it ought to have one or two days of light work and one day off (Boldt, ch. 3, p. 170).

Finally, one might object that our hybrid virtue does not rest on any natural function. For all virtues arise out of some instinct (Sec again NE. 6. 13., 1144b12-14 and also $N E$. 2. 5., 1105b25-28). But equine virtue does rest on a natural function. Xenophon calls this function a willingness and ability to work $(E Q .3 .12$.). Boldt calls it a readiness and eagerness to work (Boldt, ch. 3, pp. 70-71). The function is simply the desire of the horse to run.

\section{V}

We see then that a horse may have virtue. A horse may not be able to have virtue in the strict sense, but it is able to have more than virtue in the natural sense. What we call a hybrid virtue is a virtue resulting from our ability to use our rationality to develop good habits in a horse and to improve its function.

And so we have a new perspective on the classical conception of virtue. The classical conception of moral virtue is applicable not only to human beings but also to other animals. At least to domesticated animals. Because we can use our rationality to create habits in them, we can also use this conception of moral virtue to analyze the habits created in these animals.

We thus appear to have discovered a new basis for the ethical treatment of domesticated animals. Because it possesses hybrid virtue, a horse would appear to be a member of our moral community. And as we ought to respect the virtue and function of another human being, so we ought to respect the virtue and function of a horse. Indeed we have a double obligation to respect equine virtue. Not only does virtue of this sort resemble strict virtue, but this virtue is also a virtue created by us. ${ }^{12}$

And we now find that several avenues of inquiry present themselves for further consideration. Another subject for inquiry would obviously be hybrid vice. To train an animal to act in an extreme fashion would clearly be to create a vice in it. And to train an animal to perform some functions might also make it vicious (see NE. 2. 6., 1107a8-27). Those who are pacifists would question the morality of training horses for military service, for example.

We have also restricted our inquiry only to horses, but we do domesticate other species, most notably dogs. And so we might ask what virtue we instill in these animals. For example, canine virtue would appear to be a hybrid virtue.

Finally we might ask about breeding animals for these functions. Are there virtuous and vicious breeds of horses? Or virtuous and vicious breeds of dogs? 


\section{Notes}

${ }^{1}$ My translations of Aristotle.

${ }^{2}$ The commentators have very little to say about Aristotle's reference to the virtue of a horse. Grant merely refers us to Republic 1., where Plato presents arguments somewhat similar. See Alexander Grant, The Ethics of Aristotle, 1885 ed., (New York: Arno Press, 1973), vol. 1, p. 498. Stewart refers us to Grant. See J. A. Stewart, Notes on the Nicomachean Ethics, 2 vols., (Oxford: Clarendon Press, 1892), vol. 1, p. 192. Dirlmeier suggests that when he here refers to virtue, Aristotle does not mean a perfect condition but only a preliminary condition, which leads to perfection. See Aristoteles, Nikomachische Ethik, trans. and comm. Franz Dirlmeier, 1956 ed., (Berlin: Akademie-Verlag, 1983), pp. 309-310. Jolif argues simply that Aristotle uses the term virtue not in a precise technical sense but in an imprecise everyday sense. See René Antoine Gauthier and Jean Yves Jolif, L'éthique à Nicomaque, 2nd ed., 2 vols., (Paris: Béatrice-Nauwelaerts, 1970), vol. 2, pt. 1, pp. 135-136.

${ }^{3}$ Contemporary philosophers especially disagree about how to interpret Aristotle's conception of practical intuition. For a discussion of alternative interpretations, see Norman Dahl, Practical Reason, Aristotle, and Weakness of the Will (Minneapolis: University of Minnesota Press, 1984), esp. app. 1.

${ }^{4}$ In this essay I shall not address the question of whether horses might have a practical rationality which is less than human rationality but which nonetheless enables them to develop good habits of their own.

${ }^{5}$ Podhajsky for example speaks very favorably of Xenophon. He also observes that modern equitation began in the renaissance with Federico Grisone, who read Xenophon thoroughly. See Alois Podhajsky, The Complete Training of Horse and Rider, trans. Eva Podhajsky and V.D.S. Williams, (New York: Doubleday and Co., 1967), esp. ch. 1, pp. 14-15.

${ }^{6}$ My revisions of the translations by Morgan and Marchant. See Xenophon, The Art of Horsemanship, trans. Morris H. Morgan, (London: J. A. Allen and Co., 1962); and Xenophon, On the Art of Horsemanship, trans. E. C. Marchant, Scripta Minora, trans. E. C. Marchant and G. W. Bowersock, Loeb Classical Library, 7 vols., (Cambridge: Harvard University Press, 1968), vol. 7, pp. 295-363.

${ }^{7}$ Harry Boldt, Das Dressurpferd, ch. 3 trans. Sabine Schmidt and Dane Rawlins, (Lage-Lippe: Edition Haberbeck, 1978).

${ }^{8} \mathrm{My}$ amendation of the translation by Schmidt and Rawlins
${ }^{9}$ Podhajsky asserts that most horses are naturally straight, and that the weight of the rider makes them crooked. See Podhajsky, ch. 1,pp. 45-46. But I suspect that the Lippizzaners are simply horses of a superior breed.

${ }^{10}$ For an overview of our relationships with horses, one might consult the Dossenbachs. See Monique and Hans D. Dossenbach, The Noble Horse, trans. Margaret Whale Sutton and ed. Margaret Forde, (Boston: G. K. Hall and Co., 1983).

${ }^{11}$ Charles O. Williamson, Breaking and Training the Stock Horse, 6th ed., (Caldwell, Idaho: Caxton Printers, Ltd., 1971).

${ }^{12}$ Rollin advocates a teleological ethics for animals. But he advocates a teleological ethics based primarily, if not exclusively, on biological functions. And these functions Aristotle would call natural virtue. Rollin thus appears not to take into account any role our rationality might play in modifying these functions. See Bernard E. Rollin, Animal Rights and Human Morality (Buffalo: Prometheus Books, 1981), pt. 1.

I wish to express my gratitude to my equestrian colleagues at Purdue University and at Bowling Green State University.

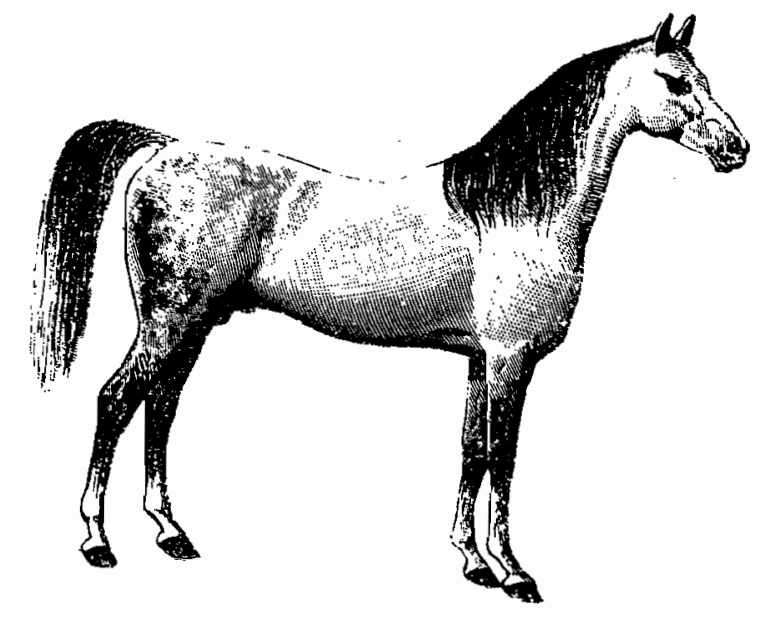

